ARTICLES

\title{
"I ALSO AM A BAROLONG": RE BETHELL AND SHAPING OF MARRIAGE LAW AND CONFLICT OF LAWS DOCTRINE
}

\section{Amanda Barratt*}

\section{ABSTRACT}

Re Bethell was a judgement of the Chancery Division in London, decided in February 1888. The case considered the validity of the marriage between an English aristocrat and a Rolong woman concluded in terms of Rolong customary law. The judgement was enormously influential as the catalyst case that secured the "legal definition of marriage" as "the voluntary union for life of one man and one woman, to the exclusion of all others". The article looks in detail at the historical context of the Bethell case and argues that the ruling was influenced by a desire to protect

* Associate Professor, Faculty of Law, University of Cape Town. 
the Bethell family's standing and reputation. The case can also be understood as a building block in the formation and consolidation of what would become the British Empire. Law was an important constituent element in the formation of Empire. Law was used to identify and legitimate colonial authority. Law created boundaries, both political and cultural. The article examines the Bethell case as an example of these dynamics.

Keywords: Marriage; customary law; conflict of laws; legal pluralism; colonisation; Rolong; Hyde v Hyde; Seedat's Executers v The Master (Natal)

\section{Introduction}

In February 1888, the Chancery Division in London gave judgement in Bethell, re; Bethell v Hildyard (hereafter Bethell). ${ }^{1}$ At its core, this was a narrow dispute concerning an inheritance: who should inherit the considerable fortune bequeathed to the late Christopher Bethell - his daughter or his brother? The court chose the brother.

However, the Bethell case is not remembered for the inheritance ruling. The case became jurisprudentially influential for its subsidiary reasoning. This relied on assessment of the validity of Christopher Bethell's marriage, concluded in terms of Rolong customary law. Bethell had married only one wife, a Rolong woman, born Tepo Baobile. ${ }^{2}$ The court classified the marriage as "polygamous" and thus invalid under English law. Here the court relied on the 1866 decision of Hyde v Hyde and Woodmansee, which had defined marriage as "the voluntary union for life of one man and one woman, to the exclusion of all others." ${ }^{3}$ The Hyde definition of marriage was ignored until Bethell came before the Chancery Division (Hyde had never been cited in the twenty-two years since the ruling). ${ }^{4}$ Bethell had important jurisprudential impact as the "catalyst case" that enabled the (now) more famous Hyde case to exert a powerful precedent for the invalidity of potentially polygamous marriages. It was Bethell's endorsement of the Hyde judgement that gave Hyde the power to define "marriage" for more than a century. ${ }^{5}$ Indeed, the Hyde wording is still used today in contemporary family law textbooks. ${ }^{6}$

The Bethell case was also instrumental in the development of conflict of laws jurisprudence. Oppong has argued that "like many aspects of colonial law, private

1 Bethell, re; Bethell v Hildyard (1888) 38 Ch D 220.

2 Bethell's wife was referred to as Teepo in the Chancery judgement. The correct spelling of her name has been sourced from Molema 1966: 104.

3 Hyde v Hyde and Woodmansee (1866) LR 1 P \& D 130 at 133.

4 Probert 2007: 331.

5 See, for example, the discussion in idem at 331.

6 See, for example, Heaton \& Kruger 2015: 13; Herring 2016: 76. 
international law was politically employed to serve a colonial end". By the late nineteenth century, conflict of laws doctrine was confronted by an increasing number of matters that arose in the expanding British Empire. Bethell must be understood within the context of its time. This was not just a question of inheritance. This was a question of whether Rolong law should be recognised in an English court - could the Rolong join the community of nations that contributed to the growing body of private international law rules? Dicey used Bethell to illustrate the principle that the courts of civilised nations would not recognise or give effect to laws emanating from "noncivilised" peoples. ${ }^{8}$ This distinction between "civilised" and "barbarous" or between "us" and "them" was also fundamental in the development of public international law jurisprudence, particularly its willingness to recognise certain kinds of polities as potential participants in the global community of nations while denying such recognition to others. ${ }^{10}$

Bethell can be understood as one of the many building blocks that contributed to the formation and consolidation of what would become the British Empire. As Nasson has observed, the British Empire was not created according to a master plan - British authorities did not know in advance how an empire should (or could) be formed, managed and ruled. Instead, Britain's vast Empire was "a peculiarly mangled creation, seemingly pieced together almost accidentally". ${ }^{11}$ In retrospect, it is clear that law was an important constitutive element for successful Empire. ${ }^{12}$ Law was used to identify and legitimate colonial authority.$^{13}$ Law created boundaries, both political and cultural. ${ }^{14}$ In retrospect, it seems unsurprising that a British court would refuse to recognise Bethell's Rolong marriage. However, this outcome was not certain or foreseen by the participants in the matter. With the benefit of hindsight, we know that the apparent "sovereignty" of role-players, such as Rolong Chief Montshiwa, was merely a vaguely defined "quasi sovereignty" that would always be subordinate to colonial authority. ${ }^{15}$ But this, too, was unknown at the time of the Bethell events. Britain's hegemony was not preordained or inevitable. It was still uncertain how the British Empire would look. The particular contours of British imperial power were created through a series of disparate events, ${ }^{16}$ of which the Bethell case was one.

Oppong 2007: 695.

8 Dicey 1896: 30, 723-724.

9 The wording used in Bethell (n 1) at 232.

For discussion of this history, see, for example, Anghie 2005; Koskenniemi 2002; and Gong 1984.

Nasson 2006: 14.

See, generally, the argument advanced by Benton 2002.

Idem at 2.

Ibid.

Anghie 2005: 100-107. Benton 2008 uses the term "quasi-sovereignty".

Benton 2002: 9. 
This article examines the Bethell case through a detailed discussion of its facts and its historical context, and argues that the decision was a response to Bethell's unique circumstances at a particular moment in Britain's domestic and imperial history.

\section{The case}

Bethell concerned the will of William Froggatt Bethell, who had died in 1879. William Bethell had been a wealthy man. He had owned significant property holdings in Yorkshire and in Lancashire. He was able to provide generously for each of his ten children. ${ }^{17}$ Bethell concerned the bequest in favour of Christopher Bethell: two substantial Yorkshire estates at Burnhill and Hallatreeholmein. ${ }^{18}$ Initially, William had bequeathed the estates to Christopher outright, but he revoked the bequest through codicil in March 1878. ${ }^{19}$ In terms of the amended bequest, the estates would be held in trust, and the rent raised from the lands would be paid to Christopher during his lifetime. Should Christopher die leaving any child or children surviving him, the trustees had to sell the property and distribute the funds thus raised among Christopher's children. Should Christopher die without leaving any child surviving him, the estates were bequeathed to William Bethell (the eldest son). ${ }^{20}$ Christopher died in July 1884 . His only child, Grace, was born ten days after his death. ${ }^{21}$

The plaintiff in the Bethell case was the testator's eldest son, William Bethell. $\mathrm{He}$ claimed the estates at Burnhill and Hallatreeholmein on the grounds that Christopher was not survived by any child who could inherit in terms of the will. William argued that Christopher's child was illegitimate under English law and therefore excluded from the inheritance.

\section{The marriage ruling}

The court focused on the validity of Christopher's marriage to Tepo (who called herself Tepo Bethell after the wedding). ${ }^{22}$ The parties had married in Bechuanaland in terms of Rolong customary law. The established conflict of laws rule was that the validity of a foreign marriage should be assessed in terms of the lex loci celebrationis (the law of the place where the marriage was concluded). The infant's counsel cited several English precedents in support of this rule, ${ }^{23}$ but Stirling J replied from the

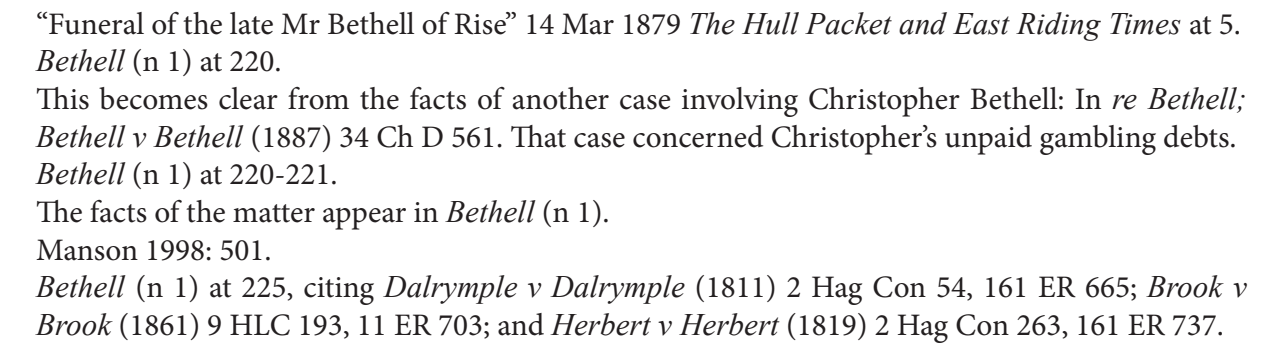


bench: "The question is whether the relationship as described by the chief of the tribe is a marriage at all." ${ }^{24}$ In the end, the court ruled that the relationship between Christopher and Tepo could not be recognised as a "marriage" in terms of English law.

Christopher Bethell had had only one wife. However, it seemed that the Rolong practised polygamy - men were permitted to have more than one wife. The court thus ruled that Christopher's marriage was polygamous in its essence. This classification of a de facto monogamous marriage as "polygamous" followed the ruling in Hyde $v$ Hyde and Woodmansee: $:^{25} \mathrm{Mr}$ Hyde had concluded a Mormon marriage in Utah. The court noted that the Mormons practised polygamy, and Mr Hyde's marriage had therefore been deemed "polygamous" even though he had had only one wife. In Hyde, the court had ruled that in England, and indeed "throughout Christendom", a marriage was the union for life of one man and one woman. ${ }^{26}$ Any marriage that had the inherent potential to become something different (in casu, through marrying a second wife) was a fundamentally different form of union - crucially, it was not a "marriage" as defined and recognised by English law. Bethell followed Hyde in ruling that a potentially polygamous marriage was not a marriage at all - even if, in reality, there was only one wife.

The Hyde and Bethell precedents were followed in several parts of the British Empire. In South Africa, for example, all Muslim marriages were deemed invalid on the ground that they were inherently polygamous. ${ }^{27}$ In the 1913 case of In re Kulsum $B i b i{ }^{28}$ the Natal Provincial Division referred to both Hyde and "the well-known case of Bethell" in reaching the conclusion that a potentially polygamous Muslim marriage would not be recognised even where the husband had only one wife. ${ }^{29}$ The court referred to several other South African judgements that had relied on Bethell to reach similar conclusions in the context of both customary and Muslim marriages. ${ }^{30}$ The Appellate Division reached the same conclusion in the 1917 case of Seedat's Executors $v$ The Master (Natal). ${ }^{31}$ The court relied on cases that had themselves relied on Bethell or Hyde when ruling that marriage is the union for life of one man and one woman, and that potentially polygamous marriages were invalid. ${ }^{32}$ This Appellate

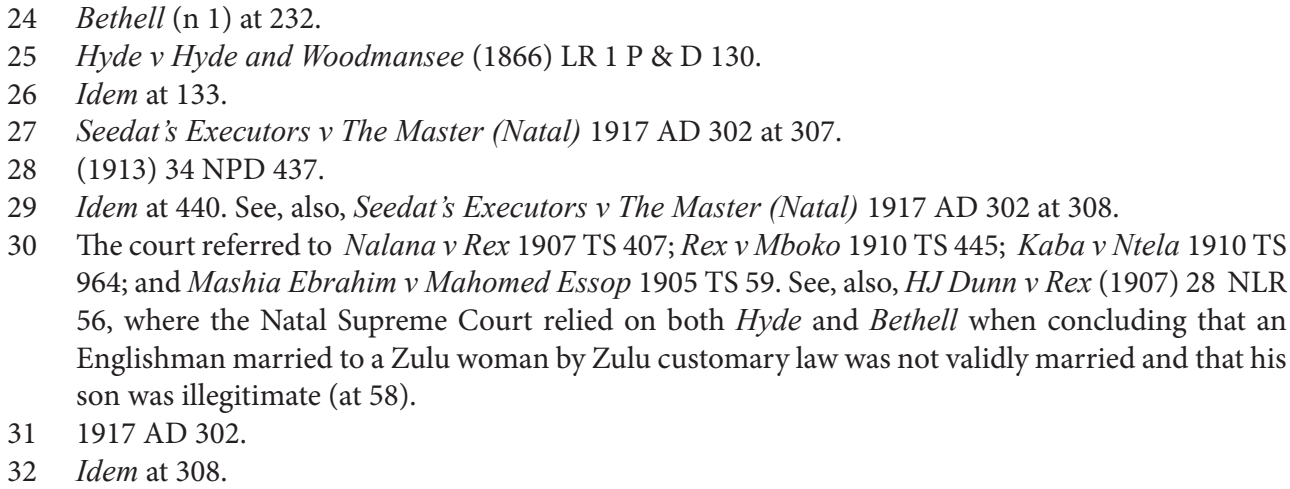


Division endorsement of the Hyde and Bethell approach has been cited in numerous South African judgements, including the 2018 challenge to the non-recognition of Muslim marriages in Women's Legal Centre Trust $v$ President of the Republic of South Africa. ${ }^{33}$

However, the Hyde interpretation of polygamy was not adopted everywhere. Some jurisdictions in the United States and Canada treated de facto monogamous unions as monogamous marriages, even if concluded in terms of a legal system that recognised polygamy. In Wall $v$ Williamson, ${ }^{34}$ for example, the Alabama court had recognised a Choctaw marriage between a white man and a Choctaw woman. The marriage had been concluded in Choctaw country according to Choctaw custom, which allowed for polygamy. The court recognised the marriage on the grounds that it was valid in terms of the lex loci celebrationis. ${ }^{35}$ The court cited the English case of Warrender $v$ Warrender $^{36}$ (which had refused to recognise a polygamous marriage), but distinguished the Choctaw case from Warrender on the grounds that the Choctaw marriage was monogamous in practice. ${ }^{37}$ In Morgan $v$ M'Ghee, ${ }^{38}$ the Tennessee court reached a similar conclusion about a Cherokee marriage between a white man and a Cherokee woman, which was monogamous in practice. In the Canadian case of Connolly $v$ Woolrich, ${ }^{39}$ the court recognised a de facto monogamous marriage between a white man and a Cree woman that had been concluded according to Cree custom (which provided for polygamy).

In some jurisdictions, the courts distinguished between a first marriage and subsequent additional marriages. In 1863, the Natal Supreme Court recognised a first marriage between an Englishman and a Zulu woman concluded in terms of Zulu customary law, and deemed this marriage to be in community of property. ${ }^{40} \mathrm{In}$ some jurisdictions, additional marriages were deemed as bigamy if they purported to be legal marriages ${ }^{41}$ The alternative was to view the first marriage as the only legal marriage and to view additional wives as "concubines" of some kind. It seemed that the English courts could recognise a first marriage as a valid marriage where the legal system concerned recognised subsequent partners as legal concubines. ${ }^{42}$ Two

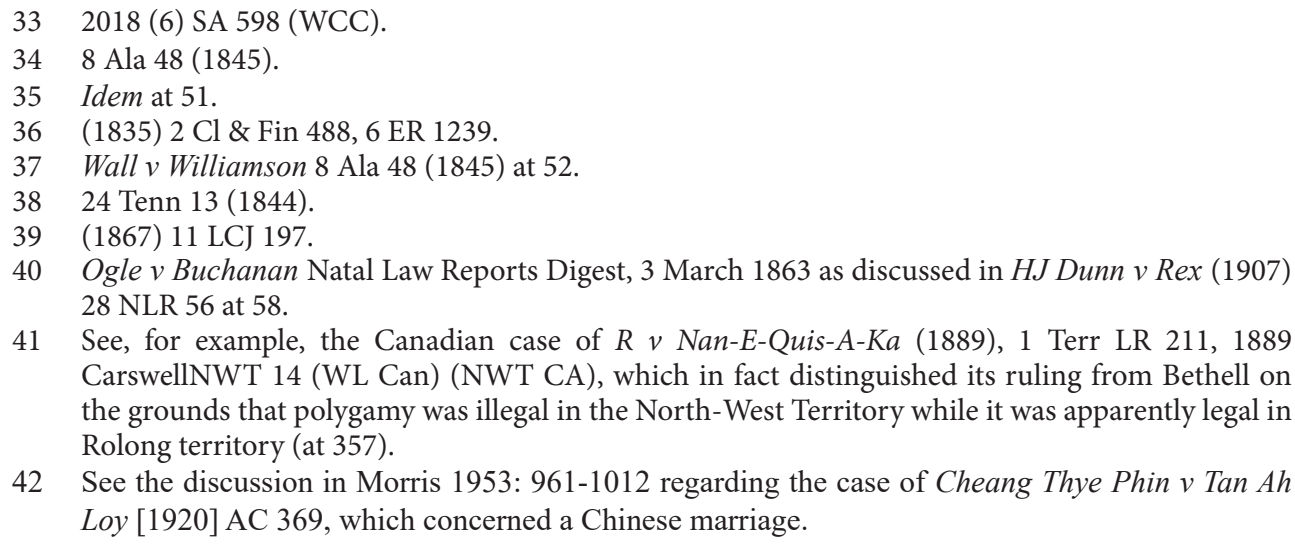

41 See, for example, the Canadian case of $R v$ Nan-E-Quis-A-Ka (1889), 1 Terr LR 211, 1889 CarswellNWT 14 (WL Can) (NWT CA), which in fact distinguished its ruling from Bethell on the grounds that polygamy was illegal in the North-West Territory while it was apparently legal in Rolong territory (at 357).

42 See the discussion in Morris 1953: 961-1012 regarding the case of Cheang Thye Phin v Tan Ah Loy [1920] AC 369, which concerned a Chinese marriage. 
years after the Bethell case, in Brinkley $v$ Attorney General ${ }^{43}$ the Chancery itself recognised a Japanese marriage. There was only one wife, but at that time, Japanese law recognised subsequent partners as legal concubines. ${ }^{44}$

These approaches were available to the Bethell court. Tepo was the only wife, and the marriage was monogamous in practice. Stirling J could have recognised the marriage as a de facto monogamous marriage based on evidence presented that Christopher had never intended to take a second wife, and that both Christopher and Tepo were Protestants (rather than Mormons) ${ }^{45}$ Furthermore, Chief Montshiwa had provided evidence that in terms of Rolong law, the first wife was the "great wife" who had a different and superior status from any other subsequent wives. Indeed, some of the witnesses described the subsequent wives as "concubines". ${ }^{6}$ This made Rolong custom materially different from Mormon practice, where all wives had equal status. Judge Stirling could have ruled that Tepo was Christopher's only "great wife" and that a first Rolong marriage would have legal consequences, even if subsequent marriages would not be recognised.

The ruling on the invalidity of the marriage was a possible conclusion - based on Hyde - but not an inevitable one, because the Bethell facts were distinguishable. In any event, the Chancery Division was not strictly bound by the Hyde precedent, because Hyde was decided in the new Court for Divorce and Matrimonial Causes, and this was not a superior court to the Chancery.

However, if we consider the marriage in the context of the Bethell family and the specific colonial context, we can understand why the court was inclined to rule against the validity of the marriage.

\section{The context of the case}

\section{Christopher Bethell of Rise Hall}

To understand the Bethell case, it is necessary to understand Christopher Bethell of Rise Hall, Yorkshire. Christopher was born into the English aristocracy in March 1856. ${ }^{47}$ It is significant that the case concerned the marriage of a member of a prominent family.

During the latter part of the nineteenth century, the English landed gentry still held their position as powerful and influential leaders of society. Members of this

\footnotetext{
(1890) 15 PD 76.

Morris 1953: 974.

Re Bethell Deposition Papers held by the National Archives, Kew. Records of the Supreme Court of Judicature. High Court of Justice, Chancery, King's Bench Division. Depositions. A-B. 1886 April-June [BNA J17/101].

46 Ibid.

4730 Dec 1864 Hull Packet and East Riding Times at 5.
} 
class "accepted, implicitly and absolutely, an unequal and hierarchical society, in which their place was undisputedly at the top" ${ }^{48}$ This elite owned most of the land in England. ${ }^{49}$ They comprised the majority of members of Parliament, ${ }^{50}$ the judiciary, ${ }^{51}$ the magistracy ${ }^{52}$ and the military officer ranks. ${ }^{53}$ The group exercised enormous power, both formal and informal. Membership of this elite depended primarily upon landownership and pedigree. ${ }^{54}$

The Bethell family of Rise Hall and Watton Abbey had a long Yorkshire pedigree dating back to the sixteenth century. Bethells had occupied the property at Rise since $1570 .{ }^{55}$ Sir Hugh Bethell, the first Bethell to occupy the property, was knighted by Queen Elizabeth I. ${ }^{56}$ Over the centuries, the Bethells of Rise Hall had been the magistrates,${ }^{57}$ members of Parliament,$^{58}$ members of the Crown Court at York ${ }^{59}$ and had held the office of Sherriff of Yorkshire. ${ }^{60}$ The Bethells were one of the leading landholders in Yorkshire, with 13400 acres in East Riding alone. ${ }^{61}$ There were only 200 landowners of 13400 acres or more in all of England at that time, ${ }^{62}$ and the Bethells belonged to this elite group. Most of the great English landowners were members of the peerage, ${ }^{63}$ and William Bethell might have wondered why he was consistently overlooked when new peers were created every year. ${ }^{64}$

Membership of the elite also required compliance with the codes of conduct for members of this class. ${ }^{65}$ It was essential to preserve family honour and reputation. ${ }^{66} \mathrm{It}$ was essential to follow a path that would benefit the family, for example by following an honourable career in politics, law or the military, or by concluding an advantageous marriage with another ruling class family. ${ }^{67}$

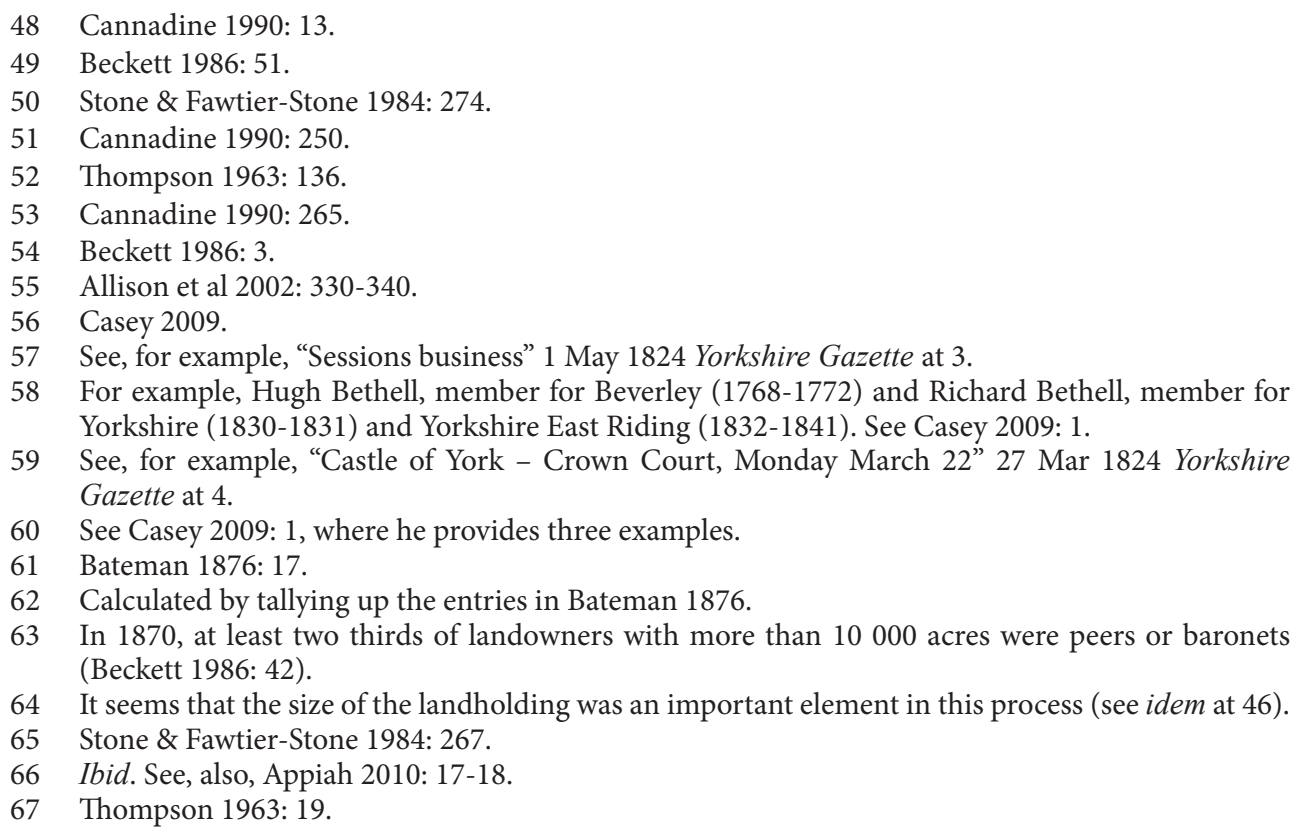




\section{"I ALSO AM A BAROLONG"}

Most members of the Bethell family performed the roles expected of the English landed gentry. Christopher Bethell's eldest brother, William, was groomed as heir to the family seat at Rise Hall. William was educated at Eton and Oxford. ${ }^{68} \mathrm{He}$ married a suitable partner, Elizabeth, youngest daughter of Henry, the eighth Baron Middleton. ${ }^{69}$ Christopher's younger brothers, George and Alfred, became officers in the British armed forces, and served as members of Parliament. ${ }^{70}$

But Christopher was different, even as a child. In a letter, his uncle, Edmund Beckett (first Baron Grimthorpe), reported that rheumatic fever had spoilt Christopher's early education, "and consequently much of his life". ${ }^{71}$ He wrote that Christopher might have had a successful career at the Bar or as an engineer, "but he had an early taste for roving and could not and would not take to literature, either at Cambridge or in London: and so his father let him go to South Africa, where he became a new man, as we have heard from several of his friends, and gradually, very useful to the Government".72

Beckett's letter hints at some of the ways in which Christopher had been a difficult member of the Bethell-Beckett clan. In March 1878, Christopher himself reported that he had been "bundled off to the Cape for a year on the shortest notice by an infuriated parent" ${ }^{73}$ The same month, Christopher's father, William, amended his will, revoking the land-bequests previously made in favour of Christopher, and directing that the estates instead be held in trust. ${ }^{74}$ It appears that young Christopher (then twenty-one years of age) had a taste for gambling, and had already accrued considerable debt that he was unable to pay. ${ }^{75}$ The gambling debt was a threat to the family honour, exacerbated by vague rumours that Christopher had been expelled from a London club for cheating at cards. ${ }^{76}$

Christopher was delivered into the care of a kinsman, ${ }^{77}$ Colonel Charles Warren (later, General Sir Charles Warren, "a famous fighting general"). ${ }^{78}$ Bethell served as Warren's orderly during Warren's 1878 campaigns in Griqualand and Bechuanaland. ${ }^{79}$ Bethell impressed Warren with his "intrepid conduct under fire" and Warren

68 "Funeral of the Late Mr Bethell of Rise" 14 Mar 1879 The Hull Packet and East Riding Times at 5.

69 "Death of the Hon Mrs Bethell" 14 Nov 1900 Daily Gazette for Middlesbrough at 3.

70 See, for example, "Death of Captain GR Bethell: Sailor and politician" 5 Dec 1919 Yorkshire Post at 6.

71 See the letter by Edmund Beckett dated 19 Sept 1884, published as "Mr Bethell's murder by the Boer - To the Editor of the Morning Post" 20 Sept 1884 Morning Post (London) at 3.

Ibid.

In re Bethell; Bethell v Bethell (1887) 34 Ch D 561 at 562.

Bethell (n 1) at 220.

This emerges from the facts of In re Bethell; Bethell v Bethell (1887) 34 Ch D 561.

76 On the honour code, see Appiah 2010: 17-18. For the disapproval of gambling and debt in general, see Stone \& Fawtier-Stone 1984: 267. For rumours of cheating, see Sillery 1971: 109.

77 Warren was related to Bethell's mother through marriage. See Manson 1998: 487.

78 "Death of famous fighting General" 22 Jan 1927 Yorkshire Evening Post at 8.

79 Reports by Colonel Warren and Captain Harrell of the Affairs of Bechuanaland, Dated April 3rd 1879 and April 27th 1880 House of Commons Sessional Papers (HCSP) 49:169 (1883) Command Paper 3635 at 3. 
promoted him to the rank of lieutenant in charge of the Intelligence Department. ${ }^{80}$ Christopher's involvement with Warren seemed to have been a successful solution for this "problem member" of the Bethell family. It seemed that Christopher could have a successful military career and bring honour to his family.

\section{Christopher Bethell of Bechuanaland}

Warren's 1878 to 1879 campaign in Bechuanaland was intended to secure British economic interests, primarily the diamond fields and surrounding regions. ${ }^{81}$ This area was extremely unstable during the period. The British had tried to resolve competing claims to the diamond fields through the Keate Award in $1871 .^{82}$ The British were particularly concerned to deny Boer claims in the district, and the Keate Award thus recognised many of the territorial claims made by the Rolong and Tlhaping who lived in the region, in order to create a buffer zone between the Transvaal Boers and the diamond fields. ${ }^{83}$ The Boers were required to remain to the east and south of the Keate boundary lines. ${ }^{84}$

Chief Montshiwa of the Tshidi Rolong claimed sovereign authority over a large area from the Harts River in the south, to the Setlagole River in the west, and to the Ramatlabama River in the north. This claim included the Molopo River basin. ${ }^{85}$ Some of Montshiwa's claims ${ }^{86}$ were recognised by Britain in the Keate Award, but during the years that followed the Keate order, Chief Montshiwa frequently complained about Boer incursions into his territory. He complained that the Boers (and their Ratlou allies) crossed the Keate boundary, took control of important water sources, and stole cattle and wheat. He appealed to the British to send a British Resident who could contain the Boers beyond the boundary. ${ }^{87}$

The British had always regarded Montshiwa as an important ally. ${ }^{88}$ Montshiwa had supported the British in various skirmishes between the British and the Boers

80 See the letter by Charles Warren dated 19 Aug 1884, published as "The late Mr Christopher Bethell - To the Editor of The Times" 21 Aug 1884 The Times (London) at 12.

81 For an account of Warren's activities in the region from 1878 to 1879, see Reports by Colonel Warren and Captain Harrell of the Affairs of Bechuanaland, Dated April 3rd 1879 and April 27th 1880 HCSP 49:169 (1883) Command Paper 3635 at 3-8.

82 Shillington 2011: 63.

83 Ibid; Comaroff \& Comaroff 1991: 284.

84 See the detailed reports in Report of the Commissioners Appointed to Inquire into and Report upon All Matters Relating to the Settlement of the Transvaal Territory (1882) HCSP 28:493 (1882) Command Paper 3114 at 73-89.

85 Montshiwa's claim is marked on the Map of the Keate Award Territory, Nov 1880 appended to idem.

86 The 1871 Keate Award recognised and endorsed a Tshidi Rolong area of more 5000 square miles. However, Chief Montshiwa claimed additional territory. See, for example, idem at 23.

87 See "Minutes of 9th February 1877, subsequent interview accorded to Chief Montsioa [Montshiwa]" enclosed in Correspondence Respecting War between Transvaal Republic and Neighbouring Native Tribes, and Native Affairs in South Africa HCSP 60:545 (1877) Command Paper 1883 at $95-96$.

88 Shillington 2011: 114. See, also, Molema 1966: 78. 
leading up to the British annexation of the Transvaal in $1877 .{ }^{89}$ Thus Warren's Bechuanaland campaign specifically included assistance to Montshiwa in his troubles with the Boers. ${ }^{90}$ Christopher Bethell played an active role in the campaign. Warren sent Bethell to assist Chief Montshiwa at his capital Sechuba, where Bethell led Warren's forces against the Boers who threatened the Tshidi Rolong. ${ }^{11}$ In 1879, Warren placed Bethell in command of a force comprising Tshidi Rolong when they advanced against Boer and Ratlou insurgents. ${ }^{92}$

However, Britain's willingness to offer military assistance to Chief Montshiwa lessened considerably following a change in British colonial policy. After Gladstone's Liberals took office in 1880, British policy became decidedly non-interventionist. ${ }^{93}$ In 1880 , the British withdrew official military support to Montshiwa. ${ }^{94}$

Bethell, however, decided to stay at Sechuba, and he entered into Chief Montshiwa's service. Bethell's decision to remain in Montshiwa's service in defiance of official policy was controversial in Whitehall. South African colonial officials, including the British High Commissioner, Sir Hercules Robinson, were also dismayed by Bethell's activities, which included active military service leading out Montshiwa's legions against the Boers. ${ }^{95}$ Certainly, Bethell was involved in the illegal purchase of arms for Montshiwa's army. ${ }^{96}$ These matters were discussed in the British House of Commons, ${ }^{97}$ and reported in the British press. ${ }^{98}$ It was clear that the authorities did not always approve of Mr Bethell. ${ }^{99}$

During this period, Britain and the Transvaal were involved in open warfare, culminating in the British defeat at Majuba in February $1881 .{ }^{100}$ British authorities

89 For examples of the British attitude to Chief Montshiwa as an important ally, see the correspondences enclosed in Correspondence Respecting the War between the Transvaal Republic and Neighbouring Native Tribes, and Generally with Reference to Native Affairs in South Africa HCSP 60:353 (1877) Command Paper 1748. See, also, Molema 1966: 78.

90 For an account of Warren's activities in the region between 1878 and 1879, see Reports by Colonel Warren and Captain Harrell of the Affairs of Bechuanaland, Dated April 3rd 1879 and April 27th 1880 HCSP 49:169 (1883) Command Paper 3635 at 3-8.

91 See the letter by Warren (n 80) at 12.

$92 \mathrm{Ibid}$. The context of this campaign is explained in Shillington 2011: 115-117.

93 Shillington 2011: 124; Sillery 1971: 62.

94 Letter by Warren (n 80) at 12. By this time, Warren himself had left South Africa after sustaining a riding accident (Sillery 1971: 47).

95 See Enclosures 29 and 30 to Further Correspondence Respecting the Affairs of the Transvaal and Adjacent Territories HCSP 47:951 (1882) Command Paper 3419.

96 Manson 1998: 497.

97 See, for example, Hansard UK House of Commons Debates no 268 (Commons Sitting 24 Apr 1882) cols 1268-1269; and no 281 (Commons Sitting 12 Jul 1883) col 1214.

98 See, for example, "The Bechuanaland Troubles" 10 Aug 1883 Morning Post (London) at 2; "Bechuanaland" 10 Aug 1883 Leeds Mercury at 7.

99 Enclosures 29 and 30 to Further Correspondence Respecting the Affairs of the Transvaal and Adjacent Territories HCSP 47:951 (1882) Command Paper 3419.

100 Davenport \& Saunders 2000: 208-209. 
tried to maintain cordial relations with the South African Republic thereafter. They were annoyed when Bethell antagonised the Boers through his correspondence with the Volksraad in Pretoria. ${ }^{101}$

Some of Bethell's complaints to Pretoria (and Cape Town and London) were specifically about the Boers who had established a new state, called Goshen, near Mahikeng in the heart of Montshiwa's territory. ${ }^{102}$ Goshen was one of two renegade Boer Republics. The other new "Boer state" was called Stellaland (with its town Vryburg) and was in the heart of Tlhaping territory as recognised by the Keate document. ${ }^{103}$

In February 1884, as the Goshen and Stellaland Boers became increasingly difficult to control, the British government agreed to intervene in southern Bechuanaland. Reverend John Mackenzie of the London Missionary Society was appointed as Deputy Commissioner to Bechuanaland. ${ }^{104}$ Mackenzie appointed Bethell as Chief of the Frontier Police. ${ }^{105}$ Bethell and the Rolong people welcomed this indication of British protection. ${ }^{106}$

The Boer renegades at Goshen were unhappy about the turn of events, however, and responded by deliberately provoking the Tshidi Rolong. On 31 July 1884, the Goshen Boers rode onto Rolong land, stole Rolong cattle and deliberately drove the stolen cattle within sight of Montshiwa's capital at Sechuba. The Rolong responded. It was later reported to the British High Commissioner by Commander Bower that Christopher Bethell, Israel Molema (Montshiwa's nephew and heir) and about 300 Rolong men had pursued the Boers. There was a significant skirmish, during which about 100 Rolong fighters were killed. Both Bethell and Molema were wounded. Bethell had been shot in the face and had lost an eye. Bethell then gave his rifle to Molema and said: "Fight for me, I am wounded." Molema replied that he could not since he was wounded himself and ammunition was running short. Molema's horse had run off, and Bethell urged Molema to take his horse and make his escape. However, Molema was too seriously injured to do so. When dusk fell and the firing stopped, some Boers approached Bethell and Molema. At this point, Molema feigned death. The Boers spoke to Bethell, however, and said: "Do you wish to live or die?" Bethell was eager to distract the Boers from Molema and said "I wish to die". At this

101 This is evident in the official communications between British officials and the Transvaal Government. (See Manson 1998: 492-493, citing papers from the Transvaal Archives in Pretoria.)

102 Shillington 2011: 136

103 Ibid.

104 Shillington 1985: 150.

105 Reported in a letter from William Bethell to the Colonial Office, enclosed in Further Correspondence Respecting the Affairs of the Transvaal and Adjacent Territories HCSP 57:205 (1884-85) Command Paper 4252 at 11.

106 Mackenzie 1887: 227. 
point, the Boers shot Bethell, and after he was dead, they crowed "Now, Bethell, come and fight us!"107

It was a version of this story that first appeared in the newspapers in late 1884 as the news reached England. Christopher Bethell's "savage murder by the Boers" was reported widely for several months. ${ }^{108}$ The Bethell and Beckett families took steps to ensure that the matter received considerable positive publicity. Christopher's brothers, George and Alfred, wrote letters to the newspapers, ${ }^{109}$ as did Christopher's uncle, Edmund Beckett, ${ }^{110}$ and his kinsman, Charles Warren. ${ }^{111}$ Christopher's uncles in the House of Commons spoke of the death in the House. ${ }^{112}$

The Bethell and Beckett families were concerned about family reputation. Those who knew Christopher's history in Bechuanaland had previously described him as hot-headed, impulsive and irresponsible. It was not always clear whether Christopher's actions had official sanction or approval. It was sometimes doubtful whether Christopher's loyalty lay with British interests - Christopher acted on behalf of the Tshidi Rolong, regardless of whether Britain approved or not. ${ }^{113}$

The family wanted to ensure that Christopher emerged as an honourable British loyalist who had died a hero. In the end, it became clear that Bethell's death could be understood as the murder of a British officer who died in service of his country. A full military funeral was arranged in Bethell's honour. ${ }^{114}$ Bethell as the loyal English patriot became the dominant narrative in Parliament and in the press. Family honour was secured.

107 This report is contained in "Memorandum from Commander Bower, R.N. to High Commissioner" Sept 20 1884, Enclosure no 82 to Further Correspondence Respecting the Affairs of the Transvaal and Adjacent Territories HCSP 57:161 (1884-85) Command Paper 4213 at 135-136. The incident regarding the horse is reported in a letter from Assistant Commissioner Wright to Mr GR Bethell (Christopher's brother), which is enclosed in the same Command Paper 4213 at 145.

108 See, for example, "The murder of Mr C Bethell" 28 Oct 1884 The Times (London) at 6; "The murder of Mr Charles [sic] Bethell by Boers" 18 Sept 1884 Morning Post at 6.

109 See, for example, the letter from Alfred Bethell, published in 25 Sept 1884 Standard at 6; and the letter from George Bethell, published in 25 Oct 1884 Standard at 3.

110 See Beckett's letter (n 71) at 3.

111 See Warren's letter (n 80) at 12.

112 See, for example, the reports in 28 Sept 1884 Yorkshire Gazette at 4; and 30 Oct 1884 York Herald at 5. The death of Christopher Bethell and the possible reprisals against those responsible was debated extensively and frequently in both the House of Commons and the House of Lords over a period of several months. See, for example, Hansard UK House of Commons Debates no 293 (Commons Sitting 27 Oct 1884) cols 246-250; idem (Commons Sitting 28 Oct 1884) cols 343-346; idem (Commons Sitting 29 Oct 1884) cols 441-514; Hansard UK House of Commons Debates no 296 (Commons Sitting 30 Jul 1885) col 534; and idem (Lords Sitting 26 Mar 1885) col 621.

113 See Enclosures 29 and 30 to Further Correspondence Respecting the Affairs of the Transvaal and Adjacent Territories HCSP 47:951 (1882) Command Paper 3419. See, also, Sillery 1971: 109.

114 "Military funeral accorded to remains of late Mr Bethell" 17 Mar 1885 Port Elizabeth Telegraph at 2-3. 
Family honour would be threatened three years later, however, when the Bethell case reached the Chancery and Christopher's Rolong marriage became the news of the day.

\section{The court's approach to the evidence}

When the Chancery court examined Christopher Bethell's Rolong marriage, the court was already familiar with some of Christopher's history. It knew that Christopher was a member of a prominent Yorkshire family who had been sent to South Africa in disgrace (Stirling J himself had given judgement on the gambling debt in January 1887). ${ }^{115}$ The court would also have been aware of the ongoing press coverage of Christopher's death. The Bethell family had ensured that the family name emerged with its reputation enhanced: Christopher had died a hero, an English officer and gentleman, defending the interests of important British allies from the unscrupulous dealings of Boer renegades.

Despite the ongoing investigations into Christopher's death in Bechuanaland and the extensive publicity that followed, it seems that Christopher's marriage remained hidden. The news of the marriage now made a sensational story: "The romantic marriage of the late $\mathrm{Mr} \mathrm{C}$ Bethell"; ${ }^{116}$ "A romance in real life - the late Commander Bethell and his African bride"; 117 "The extraordinary marriage romance"; 118 "Romantic marriage story"; 119 "Bethell marriage romance"; ${ }^{120}$ "Commander Bethell's marriage with an African girl - a romance of the law courts". ${ }^{121}$ The newspapers reminded readers that Bethell had made headlines three years earlier when he had died an honourable British officer savagely murdered by renegade Boers. ${ }^{122}$

Press coverage was not unsympathetic to Christopher and his bride, but the press also expressed grave doubts about whether Christopher's widow and daughter could take up their places as members of the English gentry. The Standard remarked that many readers might be sympathetic to Tepo and her child, but in practice, the marriage would have ramifications that would not be evident to readers with no personal acquaintance with tribal Africans: "A sensible man who has travelled - with his eyes open - among [tribal peoples] cannot regard the prospects of that child without dismay. Granting that Teepoo, or Mrs Bethell, be as good a woman as they make them among the Barolongs," she would never be suitable for membership of the Yorkshire gentry: Tepo was "too old to be civilised - to be taught those ways

115 In re Bethell; Bethell v Bethell (1887) 34 Ch D 561.

11621 Dec 1887 York Herald at 6.

11716 Dec 1887 Daily Gazette for Middlesbrough at 4.

11821 Dec 1887 Yorkshire Post at 6.

11917 Dec 1887 Yorkshire Gazette at 10.

12016 Feb 1888 South Wales Echo at 3.

12116 Dec 1887 Northern Echo (Durham) at 3.

122 See, for example, ibid; and "Mr Christopher Bethell's marriage" 21 Dec 1887 Leeds Mercury at 7. 
of thinking which should be instilled into a girl entitled to considerable property in Yorkshire". ${ }^{123}$

The Bethell family were concerned about the family's standing and reputation. These might be threatened if Christopher's widow or daughter had legal claims to membership of the family. William Bethell held extensive estates in Yorkshire and elsewhere, and the potential loss of the Burnhill and Hallatreeholmein estates would not have been significant. Indeed, William Bethell's counsel made it clear that the suit was "not a money matter" - it was about protecting the family. Generous financial provision would be made for the infant child. ${ }^{124}$ William's objective was to ensure that neither the daughter Grace, nor the wife Tepo had any claim to legal recognition as members of the Bethell family. The family required a ruling that the Rolong marriage was not really a marriage and could not be recognised in England.

The court arranged for evidence to be collected from Bechuanaland so as to understand the precise circumstances of the marriage. ${ }^{125}$ Close examination of the original depositions reveals the concerns of those who were asking the questions. It also reveals that the court was somewhat selective in the evidence chosen for incorporation into the judgement. This selectivity sheds some light on the court's interpretation of the evidence.

Witnesses were asked whether Christopher and Tepo had an exclusive relationship and whether Christopher was likely to take additional wives. The court did not rely on this evidence in its judgement. The court chose to quote from the deposition taken from John Wright (clerk to the Resident Magistrate at Mahikeng), who reported that Bethell had not told him he was married, but had referred to Tepo as "that girl of mine". ${ }^{126}$ However, the court did not consider the evidence of Edgar Rowland (storekeeper at Mahikeng), who reported that Bethell was married to Tepo. Asked if Bethell intended to take any additional wives, Rowland replied "No. Certainly not". ${ }^{127}$ A local trader, Alfred Marsden, agreed with Rowland's evidence. ${ }^{128}$

In fact, it would not have been unusual for the marriage to have remained monogamous. Polygamy rates had probably never been high among the Rolong, ${ }^{129}$ and polygamy rates fell even further with the spread of Christianity. ${ }^{130}$ While Chief Montshiwa himself had refused to convert to Christianity, ${ }^{131}$ many of the Rolong

123 "Domestic difficulty" published by the Standard and reprinted in 24 Dec 1887 Yorkshire Gazette at 7. Similar concerns were raised elsewhere, for example in "The romantic marriage of the late $\mathrm{Mr}$ C Bethell" 21 Dec 1887 York Herald at 6.

124 "The law courts" 2 Feb 1888 London Evening Standard at 2.

125 Re Bethell Deposition Papers (n 45).

126 Idem, Deposition of John Wright.

127 Idem, Deposition of Edgar Rowland.

128 Idem, Deposition of Alfred Marsden.

129 See Delius \& Glaser 2004: 86, reporting that polygamy rates in Sotho and Tswana communities were well under 50 per cent in the mid-nineteenth century and had fallen to about 12 per cent by the early twentieth century.

130 Idem at 95.

131 Comaroff \& Comaroff 1991: 262. 
had been baptised and attended services regularly. The Christian converts included prominent members of the Tshidi Rolong clan, including Chief Montshiwa's halfbrother, Isaac Molema, and his nephew, Israel. ${ }^{132}$ It seems that Christopher's wife and her parents were Christians. Montshiwa reported that plans had been made for the baptism of Christopher's infant daughter, Grace. ${ }^{133}$ The various depositions suggest rather strongly that the marriage of Christopher and Tepo was intended to remain monogamous.

Christopher's refusal to marry in a church was material to the court's decision. He had the option of concluding a marriage that would be legally recognised in England. According to Montshiwa's deposition, Christopher had deliberately chosen to reject a church wedding and had chosen the Rolong marriage customs instead. The core evidence in this regard was the conversation below recorded in the chief's deposition and quoted (in part) in the judgement. When Bethell informed the chief that he wished to marry:

I said to him 'You know we Barolong have a different custom to other tribes. The custom is that during courtship and after marriage, the man when he kills an ox sends the head to the girl's mother, so if you do this mother will know your intentions are honourable.' Bethell said: 'Well I want to marry a Barolong and I will do so according to Barolong custom. I also am a Barolong.' I said: 'Will you not marry her in Church?' He said: 'No. I am a Barolong. Did you marry your wives in church? Did you not also marry in the custom I am about to do?'134

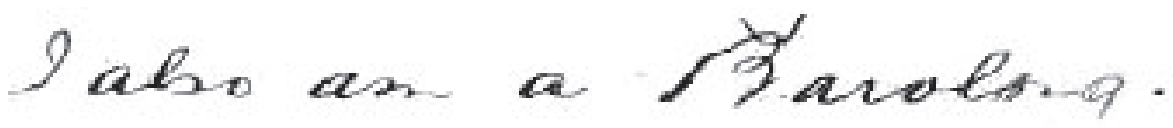

It is interesting to note that this part of the deposed evidence was changed slightly in the reported judgement. The original (as quoted above) creates an impression that Bethell was saying that he wished to marry according to Rolong custom because "I also am a Barolong". This causal relationship is lost in the reported case, which quotes the evidence as: "Well, I want to marry a Baralong, and I will do so according to Baralong custom"; also "I am a Baralong". 135

Montshiwa agreed to the marriage and Bethell duly slaughtered an ox and sent the head to his proposed bride's mother. Montshiwa then approached the mother and said: "Give your daughter to Bethell. You see he really means it. See he has sent you the head." The mother agreed to the marriage, and according to the chief, Bethell then "married her exactly in accordance with our customs. There is no other ceremony except taking the girl". ${ }^{136}$

132 Ibid.

133 Re Bethell Deposition Papers (n 45), Deposition of Chief Montshiwa.

134 Ibid.

135 Bethell (n 1) at 222.

136 Re Bethell Deposition Papers (n 45), Deposition of Chief Montshiwa. 
The court's interpretation of Christopher's refusal to conclude a church wedding was that Christopher had not intended his marriage to Tepo to have legal consequences in England, that Christopher had not viewed his union with Tepo as a "real marriage", but merely as a legally inconsequential "marriage in the Rolong sense". The Bethell family supported this interpretation. The family presented evidence that Christopher had never informed them of the marriage, ${ }^{137}$ thus suggesting that he did not really consider Tepo as his "wife" as understood in English law.

Historians have remarked on how the creation of the British Empire provided sexual opportunity and freedom to young Englishmen. ${ }^{138}$ Once away in the colonies, they were released from the strictures and expectations of English society at home. There were plenty of women who, according to stereotype, were sexually adventurous, and would welcome the attentions of an Englishman. ${ }^{139}$ Often, the colonial authorities condoned sexual liaisons between European colonists and local women. Indeed, they had encouraged such relationships in the early phases of Empire. ${ }^{140}$ It was not uncommon for British colonial officials to cohabit with local concubines. ${ }^{141}$ Sometimes, there would even be a marriage of sorts according to local custom. ${ }^{142}$ Usually, the men returned to Britain having merely abandoned the women involved, although in some cases the men made financial provision for the women and any children whom they had fathered. ${ }^{143}$

Christopher Bethell's relationship with Tepo might have been of this nature. Of course this interpretation might also threaten family reputation. It suggested that Christopher had taken advantage of Tepo, that he had been insincere and uncommitted, and that he had misled her when he married her. Counsel for the defence argued that it would be disrespectful to Christopher's memory to suggest that he was a man of so little honour that he would pretend to Tepo that he was taking her as a wife, while intending to abandon her and returning to England. ${ }^{144}$ However, the Bethell family must have decided that this interpretation of the relationship was preferable to the alternative prospect of incorporating Christopher's Rolong widow and daughter into the Bethell family.

From the family's perspective, another threat to family honour was Christopher's statement "I also am a Barolong". In order to maintain their position as a leading Yorkshire family, it was essential that Christopher be regarded as a patriotic Englishman who remained so throughout his time in Bechuanaland. Family reputation might be tarnished if Christopher had become more Rolong than English.

137 Bethell (n 1) at 233.

138 See, for example, Hyam 1990: 88.

139 Ibid.

140 Ghosh 2006: 1.

141 Idem at 29.

142 Hyam 1990: 107.

143 Ibid.

144 Bethell (n 1) at 228. 
The family had taken significant steps to ensure that Christopher would be remembered as a loyal British patriot who died protecting British interests, rather than in advancing the Rolong cause. However, one interpretation of Christopher's history in Bechuanaland was that Christopher had abandoned his English identity altogether, much like the notorious "White Zulu Chief”, John Dunn. Dunn had lived in Zululand for many years and considered himself an important member of the Zulu tribe. He had forty-seven wives whom he had married under Zulu customary law. ${ }^{145}$ Colonial officials often tolerated Europeans who had become fully incorporated into the local community. ${ }^{146}$ They were no longer representative of Britain or her interests, and could merely be classified and dealt with as any other member of the "native community". John Dunn had, in fact, received official recognition as a Zulu chief by both English and Zulu authorities. ${ }^{147}$

From the Bethell family's perspective, it was essential that the litigation did not conclude that Christopher had become incorporated into the Rolong community in the same way as John Dunn had become Zulu.

Did Bethell's conduct suggest that he had abandoned his English identity? Bethell had used the words "I am a Barolong" and his behaviour was consistent with a sincere commitment to the Rolong people and their way of life. Yet he had been an English officer when he died, and thus, unlike John Dunn, he had not abandoned his colonial heritage entirely. Furthermore, Bethell was unlike John Dunn in another way: Bethell was from the English landed gentry and had much to lose by abandoning England; Dunn was from a settler family who had abandoned their British connections generations ago. ${ }^{148}$

Indeed, Bethell's aristocratic roots would also have been a factor in the court's reasoning. While so-called "low life" 149 Europeans might be permitted to consort with local women, imperial authorities disapproved of such conduct in the case of the ruling elite. The "maintenance of a proper distance" between the rulers and the local populace "seemed not only socially appropriate but politically necessary" 150 and a marriage between an English aristocrat and a Rolong woman was greatly threatening to these boundaries. It undermined the "authority of the ruling elite and the prestige of the ruling race". 151

The court was able to resolve the various dilemmas by relying on the Hyde precedent. Christopher's Rolong marriage could not be recognised as a marriage in terms of the Hyde definition. This definition was adopted for the specific purpose

145 Hurwitz 1947: 61.

146 Rukavina 1951: 18.

147 HJ Dunn v Rex (1907) 28 NLR 56 at 61.

148 Ballard 1980: 77; Hurwitz 1947: 59.

149 Ballhatchet 1980: 139.

150 Idem at 121-122.

151 Idem at 144. 
of excluding certain types of relationships from the ambit of the legal marriage. If Christopher and Tepo's relationship was thus excluded, this would have the inevitable consequence that Tepo herself (and the infant Grace) were excluded from the Bethell family. When adopting this approach, the court could ignore the implications of Christopher's statement "I also am a Barolong". The statement became irrelevant to the court's reasoning.

Adoption of the Hyde definition of marriage as "the voluntary union for life of one man and one woman, to the exclusion of all others"152 was deliberately exclusionary. The court was not merely describing the legal institution of marriage - it was consciously drawing a clear boundary in order to exclude a potentially threatening relationship from legitimation and endorsement. The Bethell case can be understood as one of the many encounters between the colonial power and the colonised that was concerned with drawing clear boundaries between ruler and subaltern, and shaping the legitimacy and hegemony of the ruler's laws. The ruling also emphasised the boundary between Bethell and the Rolong: Bethell remained part of his English family and part of the English ruling elite.

\section{Impact on conflict of laws jurisprudence}

Dicey published the first edition of his influential Conflict of Laws eight years after the Bethell decision. ${ }^{153} \mathrm{He}$ used both Hyde and Bethell to illustrate the principle that ordinary conflict of laws principles will apply only if the foreign country concerned has "reached a similar stage of civilisation". ${ }^{154}$

That English Courts will recognise rights acquired under the law of Italy or of France is certain. That English Courts will recognise rights acquired under the law of China, under the peculiar legislation or customs of the Territory of Utah, or under the customary law of Bechuanaland, is, to say the least, uncertain. ${ }^{155}$

Bartholomew has pointed out that there was an important difference between "the customs of the Territory of Utah" mentioned in conjunction with Hyde, and the law of Bechuanaland mentioned in conjunction with Bethell. The Mormons in Utah did not have sovereignty or law-making capacity at any time, and certainly not in April $1853,{ }^{156}$ when the Hydes married in terms of Mormon doctrine. The territory had been ceded by the Republic of Mexico in 1848, but Mexican law continued to apply until Utah was incorporated into the United States. ${ }^{157}$ Thus, the law in force when the Hydes married was Mexican civil law, which did not recognise polygamy. ${ }^{158}$

152 Hyde v Hyde and Woodmansee (1866) LR1 P \& D 130 at 133.

153 Dicey 1896: passim.

154 Idem at 29.

155 Idem at 29-30.

156 Hyde v Hyde and Woodmansee (1866) LR 1 P \& D 130 at 130.

157 Bartholomew 1964: 1025, citing Hatch v Hatch (1915) 46 Utah 116.

158 Ibid. 
In Bartholomew's view, the law-making capacity and sovereignty of the Rolong of Bechuanaland was less certain at the time of the Bethell wedding (in October 1883). ${ }^{159}$ In practice, it was cases like Bethell that undermined recognition of the law-making capacity and sovereignty of African polities that had retained political independence. At the time of the Bethell marriage, Chief Montshiwa and the Tshidi Rolong were desperately trying to maintain their independence as a sovereign polity - a fact that would have been known to the Bethell court, because Christopher Bethell had died in furtherance of this objective. The Bechuanaland question had been discussed in Parliament on many occasions, and was often reported in the British press. ${ }^{160}$

At the time of the Bethell events, Chief Montshiwa of the Boratshidi Barolong identified as the sovereign leader of this group. ${ }^{161}$ As he put it: "I am Chief of my own people in my own country. My territory is on the Molopo River." ${ }^{62}$ The British had recognised Montshiwa as an "independent chief" when drawing up the Keate Award in 1871. In terms of the Pretoria Convention of August 1881, the new Transvaal State was obliged to remain within its borders and Boers were not to encroach upon territory outside of the Transvaal boundaries recognised in that document. ${ }^{163}$ In correspondence with Montshiwa in February 1883, the British authorities confirmed that they continued to recognise his independence as set out in the Pretoria Convention. ${ }^{164}$

It appears that the Chancery Division was prepared to acknowledge Chief Montshiwa as an independent sovereign within his territory. The court arranged to have evidenced deposed from the chief on Rolong law and custom. Potentially, the court could have used this evidence to support a conclusion that the usual lex loci celebrationis rule would apply.

The court's use of the available evidence illustrates how the court's deliberations drew a boundary between the "civilised" and what the court described as "barbarous or semi-barbarous". ${ }^{165}$ Here the court focused on the obvious cultural differences

159 Idem at 1052.

160 See, for example, the Times (London) reports of the House of Commons debates on Bechuanaland during the periods when Montshiwa tried to defend his territories against the Boers. There are detailed reports of the Commons debates from March to May 1883 (the year of the wedding) and of the debates in March, April, June and September 1887 (the year of the trial).

161 Re Bethell Deposition Papers (n 45), Deposition of Chief Montshiwa in the Bethell matter, 9 Apr 1886.

162 As reported in the "Minutes of an interview granted to the Chief Montsioa [Montshiwa] and Councillors by his Excellency the Administrator of Griqualand West", Kimberley, 3 Feb 1877. Enclosed in Correspondence Respecting War between Transvaal Republic and Neighbouring Native Tribes, and Native Affairs in South Africa HCSP 60:545 (1877) Command Paper 1883 at 94-95. The transcript uses the spelling "Molappo River".

163 Article 20 of The Convention of Pretoria, "Convention" for the Settlement of the Transvaal Territory, 3 Aug 1881 available at https://www.sahistory.org.za/archive/.

164 Further Correspondence Respecting the Affairs of the Transvaal and Adjacent Territories HCSP 49:195 (1883) Command Paper 3486.

165 This is the court's wording in Bethell (n 1) at 232. 
between the Rolong and the English. It was obvious that marriage rituals, such as slaughtering an ox, presenting its head to the bride's family and ploughing the motherin-law's garden, were very different from an English wedding, with a white satin bridal gown, nine bridesmaids and expensive wedding presents (as in Christopher's brother Alfred's wedding celebrated shortly before the Bethell hearing). ${ }^{166}$ This is an excellent example of how the colonial authorities endorsed and reinforced cultural hierarchies. ${ }^{167}$

Montshiwa's evidence on the marriage rituals is described accurately in the reported case. However, the judgement does not include Montshiwa's other evidence that "Bethell lived with her as man and wife until his death. The day he was killed he left her in the house. Up to the day of his death he conformed to all the native customs of acknowledging her as his wife". ${ }^{168}$ The suggestion of commitment and homely domesticity is reminiscent of an English marriage.

The court's decision to focus on what was different, rather than on what was similar, is an example of how cases like Bethell defined and ordered difference in a way that undermined the legitimacy of Rolong law and custom and shaped the hegemony of the colonial power. ${ }^{169}$ The Bethell ruling enabled influential scholars, such as Dicey, to develop their theory that the customs of "non-civilised peoples" would not be recognised as law in the context of private international law.

\section{Impact on the status and sovereignty of indigenous rulers}

The imposition of British colonial power was an uneven and gradual process. At the time of the Bethell case, the legal status of independent, never-conquered chiefs, such as Montshiwa, remained unsettled. However, the Bethell case foreshadowed and contributed to some of the devices that would eventually consolidate imperial power.

Montshiwa and the Rolong would eventually be incorporated into the Cape Colony, where the Prime Minister, Cecil John Rhodes, took the steps necessary to ensure the proletarianisation of the Rolong for the purposes of his mining enterprises. ${ }^{170}$ Other chiefs would remain nominally sovereign within their polities, notably Chief Mosheshwe of the Basotho ${ }^{171}$ and King Khama of the Ngwato. ${ }^{172}$

The Bethell case foreshadowed some of the dynamics of so-called "quasisovereign" polities within the colonial order. Nominally independent chiefs could

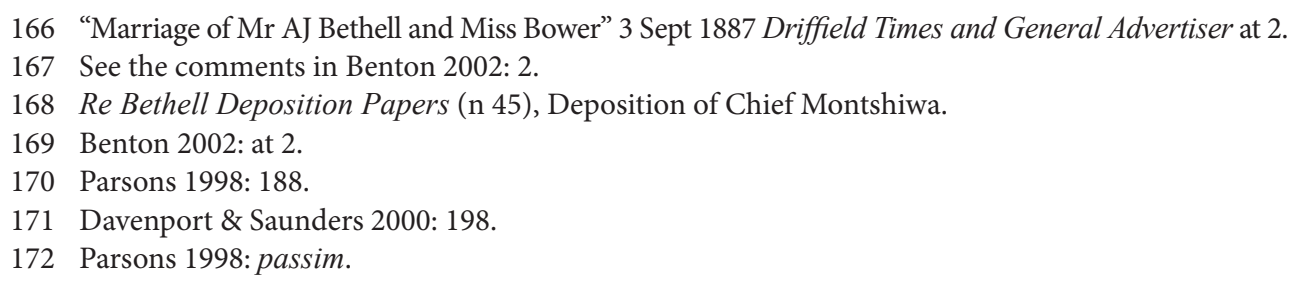


make law that would be applicable to their "own people". ${ }^{173}$ However, the law administered by the independent chiefs would not bind outsiders, such as Bethell. ${ }^{174}$ Bethell had demonstrated that he recognised the authority of Chief Montshiwa: he asked the chief's permission to marry and then performed the rituals prescribed by the chief. Despite this, the chief's law did not really bind Bethell - Bethell remained unmarried in the eyes of an English court. As the British colonial power clarified the global structure of the various laws of the Empire, this case illustrates the emergence of a system of legal pluralism in terms of which some systems of law were insulated from others, and in terms of which some systems of law were superior to others in a hierarchical structure that placed the law of coloniser at its apex. ${ }^{175}$

\section{Bethell's legacy}

Dicey's Conflict of Laws retained the distinction between the laws of the "civilised" versus the laws of the "non-civilised" until publication of the sixth edition in 1949, ${ }^{176}$ whereafter the distinction became politically unsustainable in the context of private international law ${ }^{177}$ (although the reference to "civilised states" persists in the context of public international law). ${ }^{178}$

However, Bethells popularisation of the Hyde definition of marriage as "the voluntary union for life of one man and one woman, to the exclusion of all others"179 continues to cast a shadow on contemporary jurisprudence. The wording is still used as an established legal definition of marriage. ${ }^{180}$ We should bear in mind that the definition was deliberately intended to exclude potentially polygamous unions from the definition of marriage. In Bethell's case, the definition was employed to secure the honour of a prominent English family, and to establish firm boundaries between the coloniser and the colonised.

In recent years, the definition has been quoted in order to exclude same-sex marriages. Thus it is used in a novel context, but with the same deliberate exclusionary intentions. ${ }^{181}$ It is worth remembering that the ultimate source of the definition is Christian canon law. Both Hyde and Bethell refer specifically to a "Christian marriage". The definition has no secular source in either common law or civil law, and we should

173 Benton 2002: 6.

174 For an example of this dynamic in colonial Bechuanaland, see Crowder 1988: 6.

175 Benton 2002: 127.

176 Morris 1949: 15-16.

177 Morris 1958: 10-11, discussing Dicey's reliance on the term "civilised" in earlier editions of the work, but arguing that this is not a useful distinction in private international law.

178 Fitzmaurice 2017: 359.

179 Hyde v Hyde and Woodmansee (1866) LR 1 P \& D 130 at 133.

180 See, for example, Heaton \& Kruger 2015: 13.

181 See, for example, the discussion in Bull v Hall [2014] 1 All ER 919. 
be cautious before we continue to use the definition as a "legal definition of marriage" in a secular context.

Life continued for Bethell's South African family after the judgement. Tepo remarried a few years later and moved to the Bechuanaland Protectorate (which became Botswana). ${ }^{182}$ Grace enrolled at Lovedale College in the Eastern Cape. She married an Englishman and moved to Bulawayo in 1910. ${ }^{183}$

\section{Bibliography}

Allison, KJ et al (2002) "North division: Rise" in A History of the County of York East Riding: Volume 7, Holderness Wapentake, Middle and North Divisions ed by GHR Kent (London): 330-340 available at http://www.british-history.ac.uk/vch/yorks/east/vol7/pp 330-340 (accessed 9 Mar 2019)

Anghie, Antony (2005) Imperialism, Sovereignty and the Making of International Law (Cambridge) Appiah, KA (2010) The Honor Code: How Moral Revolutions Happen (New York)

Ballard, Charles (1980) "John Dunn and Cetshwayo: The material foundations of political power in the Zulu kingdom, 1857-1878” J of African History 21: 75-91

Ballhatchet, Kenneth (1980) Race, Sex and Class under the Raj: Imperial Attitudes and Policies and Their Critics, 1793-1905 (London)

Bartholomew, GW (1964) "Recognition of polygamous marriages in America" International and Comparative Law Quarterly 13(3): 1022-1075

Bateman, John (1876) The Acre-ocracy of England: A List of All Owners of Three Thousand Acres and Upwards... (London)

Beckett, JV (1986) The Aristocracy in England, 1660-1914 (Oxford)

Benton, Lauren (2002) Law and Colonial Cultures: Legal Regimes in World History, 1400-1900 (Cambridge)

Benton, Lauren (2008) "From international law to imperial constitutions: The problem of quasisovereignty, 1870-1900" Law and History Review 26(3): 595-619

Cannadine, David (1990) The Decline and Fall of the British Aristocracy (New Haven)

Casey, Martin (2009) "Bethell, Richard (1772-1864), of Rise Hall, Holderness and Watton Abbey, Yorks" in Fisher, DR (ed) The History of Parliament: the House of Commons 1820-1832, available online at http://www.historyofparliamentonline.org/ (accessed 21 Mar 2019)

Comaroff, Jean \& John Comaroff (1991) Of Revelation and Revolution: Christianity, Colonialism and Consciousness in South Africa vol 1 (Chicago)

Crowder, Michael (1988) The Flogging of Phinehas McIntosh: A Tale of Colonial Folly and Injustice, Bechuanaland 1933 (New Haven)

Davenport, TRH \& Christopher Saunders (2000) South Africa: A Modern History 5 ed (Basingstoke)

182 Manson 1998: 507.

183 Ibid. 
Delius, Peter \& Clive Glaser (2004) "The myths of polygamy: A history of extra-marital and multipartnership sex in South Africa” South African Historical J 50: 84-114

Dicey, AV (1896) A Digest of the Law of England with Reference to the Conflict of Laws (London)

Fitzmaurice, Andrew (2017) "Scepticism of the civilizing mission in international law" in Martti Koskenniemi, Walter Rech \& Jiménez Fonseca (eds) International Law and Empire: Historical Explorations (Oxford): 359-384

Ghosh, Durba (2006) Sex and the Family in Colonial India: The Making of Empire (Cambridge) Gong, GW (1984) The Standard of “Civilization” in International Society (Oxford)

Hansard UK House of Commons Debates various volumes

Heaton, Jacqueline \& Hanneretha Kruger (2015) South African Family Law 4 ed (Durban)

Herring, Jonathan (2016) Family Law 8 ed (Harlow)

Hurwitz, N (1947) “The life of John Dunn, the White Zulu Chief” Theoria: A J of Social and Political Theory 1: 58-64

Hyam, Ronald (1990) Empire and Sexuality: The British Experience (Manchester)

Koskenniemi, Martti (2002) The Gentle Civilizer of Nations: The Rise and Fall of International Law 1870-1960 (Cambridge)

Mackenzie, John (1887) Austral Africa: Losing It or Ruling It ... vol 1 (London)

Manson, Andrew (1998) "Christopher Bethell and the Securing of the Bechuanaland Frontier, 1878-1884” J of Southern African Studies 24: 485-508

Molema, SM (1966) Montshiwa 1815-1896: Barolong Chief and Patriot (Cape Town)

Morris, JHC (ed) (1949) Dicey's Conflict of Laws 6 ed (London)

Morris, JHC (1953) “The recognition of polygamous marriages in English law" Harvard LR 66: 961-1012

Morris, JHC (ed) (1958) Dicey's Conflict of Laws 7 ed (London)

Nasson, Bill (2006) Britannia's Empire: A Short History of the British Empire (Stroud)

Oppong, RF (2007) "Private international law in Africa: The past, present, and future" American $J$ of Comparative Law 55: 677-719

Parsons, Neil (1998) King Khama, Emperor Joe and the Great White Queen: Victorian Britain through African Eyes (Chicago)

Probert, Rebecca (2007) “Hyde v Hyde: Defining or defending marriage?" Child and Family LQ 19: 322-336

Rukavina, Kathaleen Stevens (1951) Jungle Pathfinder: The Biography of Chirupula Stephenson (London)

Shillington, Kevin (1985) The Colonisation of the Southern Tswana, 1870-1900 (Johannesburg)

Shillington, Kevin (2011) Luka Jantjie: Resistance Hero of the South African Frontier (London)

Sillery, Anthony (1971) John Mackenzie of Bechuanaland, 1835-1899: A Study in Humanitarian Imperialism (Cape Town)

Stone, Lawrence \& Jeanne C Fawtier-Stone (1984) An Open Elite?: England 1540-1880 (Oxford)

Thompson, FML (1963) English Landed Society in the Nineteenth Century (London) 


\section{“I ALSO AM A BAROLONG"}

\section{Table of cases}

\section{South Africa}

HJ Dunn v Rex (1907) 28 NLR 56

In re Kulsum Bibi (1913) 34 NPD 437

Kaba v Ntela 1910 TS 964

Mashia Ebrahim v Mahomed Essop 1905 TS 59

Nalana $v$ Rex 1907 TS 407

Ogle v Buchanan Natal Law Reports Digest, 3 March 1863

Rex $v$ Mboko 1910 TS 445

Seedat's Executors $v$ The Master (Natal) 1917 AD 302

Women's Legal Centre Trust v President of the Republic of South Africa 2018 (6) SA 598 (WCC)

\section{United Kingdom}

Bethell, re; Bethell v Hildyard (1888) 38 Ch D 220

Brinkley v Attorney-General (1890) 15 PD 76

Bull v Hall [2014] 1 All ER 919

Cheang Thye Phin v Tan Ah Loy [1920] AC 369

Hyde $v$ Hyde and Woodmansee (1866) LR 1 P \& D 130

In re Bethell; Bethell v Bethell (1887) 34 Ch D 561

Warrender v Warrender (1835) 2 Cl \& Fin 488, 6 ER 1239

\section{United States of America}

Morgan v M'Ghee 24 Tenn 13 (1844)

Wall $v$ Williamson 8 Ala 48 (1845)

\section{Canada}

Connolly v Woolrich (1867) 11 LCJ 197; 3 UCLJ 14; 1 Lower Can LJ 253

$R v$ Nan-E-Quis-A-Ka (1889), 1 Terr LR 211, 1889 CarswellNWT 14 (WL Can) (NWT CA) 